\title{
Nutritional and Sensory Evaluation of Oyster Mushroom Supplemented Daily Food Items
}

\author{
Reeta Mishra*, Y.D. Mishra, P.P. Singh and B.P.S. Raghubanshi and Reena Sharma \\ RVSKVV- Krishi Vigyan Kendra, Morena (M.P.), India \\ Directorate of Extension Services, RVSKVV-Gwalior (M.P.), India \\ *Corresponding author
}

\section{A B S T R A C T}

Mushrooms are considered to be next generation health food as they are low in fat, have no cholesterol, high in protein with good biological value. Many of the micro nutrient deficiencies have been solved by various fortification strategies. Among alternate or other novel sources of proteins to bridge the protein gap in the food articles, mushroom offers themselves as a potent source of protein. The proteins of mushroom are of high quality and

\section{Keywords}

Mushroom,

Nutritional value,

Sensory evaluation, Protein

Article Info

Accepted:

10 June 2018

Available Online:

10 August 2018 rich in various essential amino acids. Keeping in view the nutritional properties of oyster mushrooms, the present study was aimed to improve the nutritional value of daily food items through incorporation of oyster mushroom in fresh as well as in dry form. The awareness programme on oyster mushroom production and its consumption was held in Model Nutri-Smart Village Bhajpura of Porsa block of Morena district of Madhya Pradesh during 2017-18 through RVSKVV-Krishi Vigyan Kendra, Morena. The farm women and adolescent girls along with anganwadi worker and supervisor were given skill training on preparation of different types of mushroom products. The protein content of fresh mushroom fortified products varied from 4.15 to 23.26 percent. Highest sodium, potassium and magnesium contents were observed in mushroom pakories, followed by mushroom potato curry and mushroom pulav, respectively. A range of 14.14 to 17.25 percent of mean values for fibre content was observed in dry mushroom fortified products. All the meal items are on the positive side of the scale (like moderately to like extremely). Mushroom pakories were liked extremely. In a nutshell, introducing mushroom into daily diet of rural farm families of Morena district of Madhya Pradesh, not only increased its nutritional quality but also increased sensory attributes. Addition of mushroom either in fresh or dry form has improved especially the nutritional content of daily food items.

\section{Introduction}

With their flavour, texture, nutritional value, very high productivity per unit area and time, less dependence on land and ability to grow on a variety of residual agricultural wastes, mushrooms have rightly been identified as a food source to fight malnutrition in developing countries (Dutta, 2007). Mushrooms present a balanced nutritional composition (Rashidi and Yang, 2016) and are considered to be an attractive and alternative source of high quality protein with essential and nonessential amino acids. In this context, amino acids play an important role in providing structure to cells, tissues and organs, becoming, therefore, 
essential for growth and cell repair (Alam et al., 2010; Wani et al., 2010; Mukhopadhyay and Guha, 2015; Teklit, 2015).

In addition, they are an excellent source of carbohydrates, dietary fibre, unsaturated fatty acids, vitamins and minerals (Teklit, 2015; Deepalakshmi and Mirunalini, 2014; Kadnikova et al., 2015; Rosli et al., 2015).

Processing of mushrooms and its fortification into ready to eat products can serve the dual purpose of prevention of post-harvest losses as well as utilization of mushrooms for the improvement of nutritional status of society (Arora and Mridula, 2014).

Pleurotus sajor-caju (PSC) improves nutrient contents and maintains sensory properties of carbohydrate-based products (Rosli and Aishah, 2012).

Keeping in view the nutritional properties of oyster mushrooms, the present study was aimed to improve the nutritional value of daily food items through incorporation of oyster mushroom in fresh as well as in dry form.

\section{Materials and Methods}

The awareness programme on oyster mushroom production and its consumption was held in Model Nutri-Smart Village Bhajpura of Porsa block of Morena district of Madhya Pradesh during 2017-18 through RVSKVV-Krishi Vigyan Kendra, Morena. The farm women and adolescent girls along with anganwadi worker and supervisor were given skill training on preparation of different types of mushroom products.

The technology was spread through other extension activities and large scale dissemination was done with the help of print media, electronic media and different ICT tools.

\section{Selection of daily meal items}

Fresh oyster mushroom was used in the daily food preparations as shown in Table 1 and 4 . Fresh mushrooms were dried and converted into powdered form. In this study, fresh (50 g) and dry mushroom powder $(10 \mathrm{~g})$ was incorporated since this level was found acceptable in earlier studies (Mane Asha et al., 2000; 2004; 2012).

\section{Nutritional content of daily meal items}

Nutritional composition of food is an important criterion in determining quality of the product. The composition depends on the ingredients used in the preparations. In this study, fresh as well as dry mushroom powder was incorporated in daily food items. Macronutrient composition is a recognized system of the assessment of the nutritional value of food items. Nutritive values of food ingredients were calculated with the help of food value tables.

\section{Sensory evaluation of daily meal items}

The sensory attributes including colour, texture, flavour taste and overall acceptability were evaluated using the 9-point hedonic scale (Lim, 2011).

The data obtained in the present investigation were calculated statistically.

\section{Results and Discussion}

Nutritional quality of fortified daily meal items

\section{Macronutrient composition of fresh mushroom incorporated food products}

The results of nutritional quality of fortified daily meal items (mushroom-potato curry, mushroom pakories, mushroom pulav, 
mushroom fortified wheat flour chapatti, mushroom fortified pearlmillet flour chapatti and mushroom namkeen sev) are presented in Table 1 to 4 .

Table 1 shows that the protein content of fresh mushroom fortified products varied from 4.15 to 23.26 percent. Maximum protein content was observed in mushroom pakories. A range of 4.71 to 5.59 percent of mean values for fibre content was observed in fresh mushroom fortified products. Carbohydrate values for these products (mushroom-potato curry, mushroom pakories and mushroom pulav) were 13.59, 16.49 and 59.93 percent respectively.

Micronutrient composition of fresh mushroom incorporated food products

The calculated potassium, sodium and magnesium values of fresh mushroom incorporated food preparations under study are given along with iron and calcium values in Table 2. The values presented are derived out of $100 \mathrm{~g}$ of total ingredients.

Highest sodium, potassium and magnesium contents were observed in mushroom pakories, followed by mushroom potato curry and mushroom pulav, respectively. Iron is present in appreciable amount in Pleurotus species. Table 2 shows that mean score of iron content in mushroom pakories was 22.85 $\mathrm{mg} / 100 \mathrm{~g}$, while the mean value of iron content for mushroom potato curry and mushroom pulav products were 19.38 and $9.51, \mathrm{mg} / 100 \mathrm{~g}$, respectively.

\section{Macronutrient composition of dry mushroom incorporated food products}

The results of nutritional quality of dry mushroom powder fortified food products (mushroom fortified wheat flour chapatti, mushroom fortified pearlmillet flour chapatti and mushroom fortified namkeen sev) are presented in Table 3. Protein content of three types of food products ranged from 11.42 to 18.31 percent (Table 3). A range of 14.14 to 17.25 percent of mean values for fibre content was observed in dry mushroom fortified products.

Carbohydrate values for these products (mushroom fortified wheat flour chapatti, mushroom fortified pearlmillet flour chapatti and mushroom fortified namkeen sev) were 61.06, 58.91 and 54.89 percent respectively.

\section{Micronutrient composition of dry mushroom incorporated food products}

Highest sodium content was observed in mushroom fortified sev namkeen $(675,11.56$ and $149.55 \mathrm{mg} / 100 \mathrm{~g}$, respectively) followed by mushroom potato curry and mushroom pulav, respectively.

The mineral content of studied food products for iron and calcium were in the range of 4.05 to 6.28 and 26.98 to $77.33 \mathrm{mg} / 100 \mathrm{~g}$, respectively (Table 4).

Among different studied food products, higher iron content was observed in mushroom fortified namkeen sev followed by mushroom fortified pearlmillet flour chapati and mushroom fortified wheat flour chapatti, which might be due to incorporation of higher level of iron in pealmillet. Highest calcium content was observed in type mushroom fortified namkeen sev.

\section{Sensory evaluation of daily meal items}

Nine-point hedonic scale was used to evaluate the acceptability of the studied products for colour, texture, flavour, taste and overall acceptability. Addition of mushroom certainly gives variety in flavour, texture and appearance of studied food items. 
Table.1 Major nutrients in daily meal items with addition of fresh mushroom

\begin{tabular}{|l|c|c|c|c|c|}
\hline \multicolumn{1}{|c|}{ Products } & \multicolumn{5}{|c|}{ Major nutrients } \\
\hline & $\begin{array}{c}\text { Protein } \\
(\boldsymbol{\%})\end{array}$ & $\begin{array}{c}\text { Crude fat } \\
(\mathbf{\%})\end{array}$ & $\begin{array}{c}\text { Carbohydrate } \\
(\%)\end{array}$ & $\begin{array}{c}\text { Total ash } \\
(\%)\end{array}$ & $\begin{array}{c}\text { Crude fibre } \\
(\%)\end{array}$ \\
\hline $\begin{array}{l}\text { Mushroom-Potato } \\
\text { curry }\end{array}$ & 4.15 & 4.56 & 13.59 & 1.60 & 4.49 \\
\hline $\begin{array}{l}\text { Mushroom } \\
\text { Pakories }\end{array}$ & 23.26 & 5.62 & 16.49 & 0.89 & 5.59 \\
\hline Mushroom Pulav & 8.53 & 4.64 & 59.93 & 1.23 & 4.71 \\
\hline
\end{tabular}

Table.2 Micronutrients (mg) in daily meal items with addition of fresh mushroom

\begin{tabular}{|c|c|c|c|c|c|}
\hline \multirow[t]{2}{*}{ Products } & \multicolumn{5}{|c|}{ Micronutrients } \\
\hline & $\begin{array}{l}\text { Potassium } \\
\text { (mg) }\end{array}$ & $\begin{array}{l}\text { Sodium } \\
\text { (mg) }\end{array}$ & $\begin{array}{c}\text { Magnesium } \\
\text { (mg) }\end{array}$ & $\begin{array}{l}\text { Iron } \\
\text { (mg) }\end{array}$ & $\begin{array}{l}\text { Calcium } \\
\text { (mg) }\end{array}$ \\
\hline $\begin{array}{l}\text { Mushroom- } \\
\text { Potato curry }\end{array}$ & 600.81 & 12.58 & 56.74 & 19.38 & 61.69 \\
\hline $\begin{array}{l}\text { Mushroom } \\
\text { Pakories }\end{array}$ & 1179.93 & 29.93 & 129.49 & 22.85 & 58.12 \\
\hline Mushroom Pulav & 360.61 & 6.62 & 52.77 & 9.51 & 48.65 \\
\hline
\end{tabular}

Table.3 Major nutrients in daily meal items with addition of dry mushroom

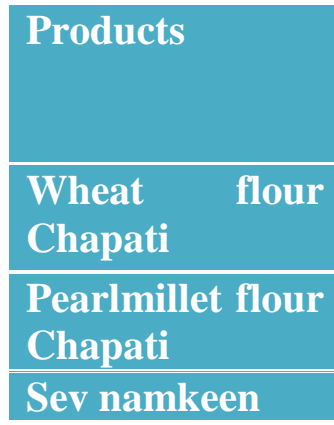

\begin{tabular}{|c|c|c|c|c|}
\hline $\begin{array}{c}\text { Protein } \\
(\%)\end{array}$ & $\begin{array}{c}\text { Crude fat } \\
(\%)\end{array}$ & $\begin{array}{c}\text { Carbohydrate } \\
(\%)\end{array}$ & $\begin{array}{c}\text { Total ash } \\
(\%)\end{array}$ & $\begin{array}{c}\text { Crude fibre } \\
(\%)\end{array}$ \\
\hline 11.42 & 1.44 & 61.06 & 1.29 & 14.14 \\
\hline 11.77 & 5.17 & 58.91 & 1.37 & 14.25 \\
\hline 18.31 & 7.27 & 54.89 & 2.04 & 17.25 \\
\hline
\end{tabular}

Table.4 Micronutrients (mg) in daily meal items with addition of dry mushroom

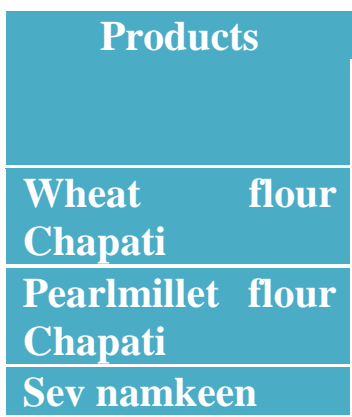

\begin{tabular}{|c|c|c|c|c|}
\hline $\begin{array}{c}\text { Potassium } \\
(\mathbf{m g})\end{array}$ & $\begin{array}{c}\text { Sodium } \\
(\mathbf{m g})\end{array}$ & $\begin{array}{c}\text { Magnesium } \\
(\mathbf{m g})\end{array}$ & Iron $(\mathbf{m g})$ & $\begin{array}{c}\text { Calcium } \\
(\mathbf{m g})\end{array}$ \\
\hline 314.9 & 2.70 & 126.1 & 4.05 & 30.21 \\
\hline 363.5 & 4.57 & 125.2 & 6.14 & 26.98 \\
\hline 675 & 11.56 & 149.55 & 6.28 & 77.33 \\
\hline
\end{tabular}


Table.5 Sensory parameters of daily food items with addition of fresh mushroom

\begin{tabular}{|l|c|c|c|c|c|}
\hline \multicolumn{1}{|c|}{ Product } & \multicolumn{1}{|c}{ Colour } & Texture & Flavour & Taste & Overall \\
M \pm S.D. & M \pm S.D. & M \pm S.D. & M \pm S.D. & $\begin{array}{c}\text { acceptability } \\
\text { M } \pm \text { S.D. }\end{array}$ \\
\hline $\begin{array}{l}\text { Mushroom- } \\
\text { Potato curry }\end{array}$ & $8.24 \pm 0.04$ & $8.06 \pm 0.04$ & $8.1 \pm 0.06$ & $8.54 \pm 0.04$ & $8.235 \pm 0.06$ \\
\hline $\begin{array}{l}\text { Mushroom } \\
\text { Pakories }\end{array}$ & $8.72 \pm 0.07$ & $8.52 \pm 0.07$ & $8.76 \pm 0.04$ & $8.9 \pm 0.08$ & $8.725 \pm 0.04$ \\
\hline Mushroom Pulav & $8.62 \pm 0.07$ & $8.22 \pm 0.07$ & $7.92 \pm 0.07$ & $8.5 \pm 0.06$ & $8.315 \pm 0.03$ \\
\hline
\end{tabular}

Table.6 Sensory parameters from addition of mushroom powder

\begin{tabular}{|l|l|l|c|c|c|}
\hline & \multicolumn{1}{|c|}{$\begin{array}{c}\text { Colour } \\
\text { M }\end{array}$} & $\begin{array}{c}\text { Texture } \\
\text { M S.D. }\end{array}$ & $\begin{array}{c}\text { Flavour } \\
\text { M S.D. }\end{array}$ & $\begin{array}{c}\text { Taste } \\
\text { M S.D. }\end{array}$ & $\begin{array}{c}\text { Overall } \\
\text { acceptability } \\
\text { M } \pm \text { S.D. }\end{array}$ \\
\hline $\begin{array}{l}\text { Wheat flour } \\
\text { Chapati }\end{array}$ & $8.42 \pm 0.07$ & $8.32 \pm 0.08$ & $8.32 \pm 0.07$ & $8.37 \pm 0.07$ & $8.37 \pm 0$. \\
\hline $\begin{array}{l}\text { Pearlmillet } \\
\text { flour Chapati }\end{array}$ & $7.52 \pm 0.07$ & $7.44 \pm 0.04$ & $7.26 \pm 0.04$ & $7.82 \pm 0.07$ & $7.51 \pm 0.03$ \\
\hline \begin{tabular}{l} 
Sev namkeen \\
\hline
\end{tabular} & $8.6 \pm 0.06$ & $8.34 \pm 0.08$ & $8.42 \pm 0.07$ & $8.58 \pm 0.07$ & $8.485 \pm 0.06$ \\
\hline
\end{tabular}

Table 5 reveals the mean scores of overall acceptability of mushroom incorporated daily meal items. The scores of studied preparations range between 7.92 to 8.9 indicating that all the meal items are on the positive side of the scale (like moderately to like extremely). The reason behind getting the acceptability was that the daily meal items were familiar ones and there was little variation in the organoleptic attributes in studied preparations. Table 5 also indicates that mushroom pakories were liked extremely. Whereas, mushroom potato curry and mushroom pulav were liked very much.

Table 6 reveals that dry mushroom powder fortified wheat flour chapaties and namkeen sev fall in liked very much category while dry mushroom powder fortified pearlmillet flour chapaties fall in liked moderately category. Mean scores of these food items indicated in
Table 6 ranges between liked moderately and liked very much category. This shows that all the studied daily meal items are acceptable. Evaluation of sensory attributes shows that addition of mushroom either in fresh or dry form does not have much effect on acceptability of food preparations. Similar results were found by the investigator in previous studies (Mane et al., 2000; Mane et al., 2004; Mane et al., 2012). Moreover, inclusion of mushroom gives variety and nutrition to the diet.

In a nutshell, introducing mushroom into daily diet of rural farm families of Morena district of Madhya Pradesh not only increased its nutritional quality but also increased sensory attributes. The fresh and dry mushroom/ mushroom powder can be incorporated in a food item to enhance its nutritive value without affecting its 
acceptability. Different mushroom products may serve to meet day-to-day nutritional requirements as a supplement.

Therefore, mushroom fortified food items can be recommended in daily diet of normal as well as malnourished individual. Addition of mushroom either in fresh or dry form has improved especially the nutritional content of daily food items. Keeping in view the improved sensory properties of studied mushroom daily meal items, they are suitable for incorporation in diet as supplementary food for vulnerable groups. Breakfast and snacks items like mushroom pakories and mushroom namkeen sev are high protein foods, hence good for preschool children.

\section{References}

Alam, N., Amin, R., Khan, A. et al., 2008. Nutritional analysis of cultivated mushrooms in Bangladesh - Pleurotus ostreatus, Pleurotus sajor-caju, Pleurotus florida and Calocybe indica. Mycobiology. 36: 228-232.

Arora, B., and Mridula, D. 2014. Nutritional and sensory properties of mushroom fortified corn extrudates. Mushroom Research. 23(1): 89-97.

Deepalakshmi, K. and Mirunalini, S. 2014. Pleurotus ostreatus: an oyster mushroom with nutritional and medicinal properties. Journal of Biochemical Technology. 5: 718-726.

Dutta, Ram. 2007. Advances in mushroom science. Satish Serial Pub. 14: 240.

Kadnikova, I.A., Costa, R., Kalenik, T.K., Guruleva, O.N. and Yanguo, S. 2015. Chemical composition and nutritional value of the mushroom Auricularia auricula-judae. Journal of Food and Nutrition Research. 3: 478-482.

Lim J. 2011. Hedonic scaling: a review of methods and theory. Food Quality Preference. 22: 733-747.
Mane Asha et al., 2000. Acceptability and protein quality of supplementary foods developed out of oyster mushroom powder. Science and Cultivation of Edible Fungi. LJLD Van Griensven Eds. pp 753-55.

Mane Asha et al., 2004. Effect of incorporation of mushroom powder on gluten formation in wheat dough used for bread making. Recent Trends in Biotechnology. Jodhpur India, Scientific Publisher. pp 102-105.

Mane Asha et al., 2012. Acceptability and nutritional quality of oyster mushroom powder supplementary foods. Proceeding of the 18th Congress of the International Society for Mushroom Science, China Agriculture Press. pp 619-622.

Mukhopadhyay, R. and Guha, A.K. 2015. A comprehensive analysis of the nutritional quality of edible mushroom Pleurotus sajor-caju grown in deproteinized whey medium. LWT Food Science and Technology. 61: 339345.

Rashidi, A.N.M. and Yang, T.A. 2016. Nutritional and antioxidant values of oyster mushroom (P. sajor-caju) cultivated on rubber sawdust. International Journal on Advanced Science Engineering Information Technology. 6: 161-164.

Rosli WIW and Aishah MS. 2012. Pleurotus sajor-caju (PSC) Improves Nutrient Contents and Maintains Sensory Properties of Carbohydrate-based Products. World Academy of Science Engineering and Technology. 6: 3-20.

Rosli, W.I.W., Maihiza, M.S.N. and Raushan, M. 2015. The ability of oyster mushroom in improving nutritional composition, b-glucan and textural properties of chicken frankfurter. International Food Research Journal. 22, 311-317. 
Teklit, G.A. 2015. Chemical composition and nutritional value of the most widely used mushrooms cultivated in Mekelle Tigray Ethiopia. Journal of Nutrition and Food Sciences. 5, 1-3.
Wani, B.A., Bodha, R.H. and Wani, A.H. 2010. Nutritional and medicinal importance of mushrooms. Journal of Medicinal Plants Research. 4: 25982604.

\section{How to cite this article:}

Reeta Mishra, Y.D. Mishra, P.P. Singh and B.P.S. Raghubanshi and Reena Sharma. 2018. Nutritional and Sensory Evaluation of Oyster Mushroom Supplemented Daily Food Items. Int.J.Curr.Microbiol.App.Sci. 7(08): 1465-1471. doi: https://doi.org/10.20546/ijcmas.2018.708.167 